Fecha de entrega: 15 de octubre de 2011

Fecha de aprobación: 15 de noviembre de 2011

\title{
IMPROVISATION: AN EMPIRICAL STUDY ON IMPROVISATIONAL ACTION
}

\author{
TEATRO DE IMPROVISACIÓN. \\ UN EXAMEN EMPÍRICO DE LA ACCIÓN IMPROVISATORIA
}

Anja Joos*

\section{Resumen}

Para la sociología, que se ocupa del orden social y los modos de interaccion, el tema de la improvisación constituye un campo de investigación emocionante. Sin embargo, solamente unos cuantos científicos sociales se han ocupado de esta forma de acción. El análisis de las acciones es a menudo realizado por las teorías clásicas de acción, por ejemplo, la teoría de Thomas Luckmann que se desarrolla en este artículo. Este trabajo pretende acercarse al tema de la improvisación y para ello se centratrá en el teatro de improvisación, el cual, hasta el momento, apenas fue investigado por los científicos sociales. El artíuculo pretende investigar cómo se desarrollan las acciones improvisatorias y qué reglas posiblemente siguen. Particularmente se analizará una escena de teatro de improvisación con el método de teoría fundamentada, para así descubrir posibles categorías de acciones.

\section{Palabras clave}

Improvisación, composición, teatro de improvisación, teoría de la acción, Grounded Theory.

\footnotetext{
* Magíster en Sociología de la Universidad de Konstanz. Sus intereses de investigación son los métodos cuantitativos y cualitativos en el ámbito de la justicia y la igualdad, y el análisis del teatro de la improvisación. Correo electrónico: Anja.Joos@uni-konstanz.de
} 


\begin{abstract}
For Sociology, that deals with social structure and interaction, improvisation would be a highly interesting research topic. Only few social scientists though conduct research in this field. The analysis of actions often uses the classical theories of action, e.g., the theory of action by Thomas Luckmann mentioned herein. This paper tries to approach the topic of improvisation with an emphasis on the improvisational theatre, where social sciences has conducted almost no research at all. The "how", the modus operandi, and possible rules applying to improvisational actions will be studied. A theatre scene will be used as a subject for the Grounded Theory method to differentiate possible categories of action.
\end{abstract}

\title{
Keywords
}

Improvisation, composition, improvisational theatre, action theory, Grounded Theory.

\section{Introduction}

All human beings improvise more or less while acting, because every action incorporates an element of improvisation. Even a simple daily-life conversation includes a large part of improvisation: neither a plot nor a director control the dialogue. Without knowing what exactly the other will say, we act spontaneously whereas interaction dominates the dialogue's development (Sawyer, 2001: 7f).

Western culture perceives improvisation negatively; it prefers a thoughtful foresight and a rational action. Not knowing the future might be contradictory to the "perhaps human, maybe culturally influenced need" to at least imagine the future and prepare accordingly, state Kurt and Näumann (2008: 12). But improvisation may hold many advantages. Allowing a situation to happen, one could be able to act more adequately, because one does not adhere to a stringent plan and more often than not the future turns out to be different. The status improvisation holds in Europe differs largely from cultures such as India or South America, where in everyday life improvisation is more common. It is completely normal to act without planning.
This paper divided into three parts. Firstly, improvisation and the improvisation theatre is explained. In the second part, its analized the theory of action and it's connection to improvisational actions. In the last part, the empirical analysis of the applied method is found.

\section{Improvisation}

Starts with a closer look at the term "improvisation", therefore improvisation will be described, defined and set in relationship to "composition". Furthermore, there will be a classification into freedom and sticking to the rules. The next part consists of a characterization and the historical development of improvisation.

\section{Improvisation, terminology and character}

The term "improvisation" is derived from Latin "improvises", which means "unexpected2 or "unforeseen" (Kurt \& Näumann, 2008: 11). Improvisation refers to situations in which arrangements cannot be made, because the unexpected situation cannot be planned for and it is not possible for us to control it. It is notable that the Latin word for improvi- 
sation did not find its way into the German language, yet it has been transformed into other European languages, such as Italian, French and English. The closest word to improvisation is the German "Stegreif", which was first described by the Brothers Grimm in the $19^{\text {th }}$ century "aus dem Stegreife, ohne große Vorbereitung, ohne lange Überlegung (with little preparation, without thinking twice)" (Grimm, in Kurt \& Näumann, 2008: 13). With this definition certain difficulties arise that especially influence recent approaches and definitions, foremost in the social sciences. "With little preparation" does not mean that no preparation is made. In some way one can perhaps foresee the future. Maybe one is aware that something unpredictable will be coming, but allows this possibility to exist (Widmer, 1994: 9).

Humanities and Social Sciences do not seem to be able to agree on one congruent definition of the term improvisation. This may be caused by the nature of improvisation, being constantly in flow, never stable or established; an exact analysis and description is impossible, its character being entirely non-academical, according to the musician Derek Bailey (in Kurt \& Näumann, 2008: 10). Recently several scientific studies are closing in on the concept of improvisation.

In general, improvisation is simply the opposite of "composition". This differentiation must be opened, though, to a wide array of additional associated characteristics. Improvisation is more likely to be associated with the childish and irrational, whilst composition is more likely to be associated with the mature and rational (Kurt, 2008: 24; Behne, 1992: 42). The creation, the product of composition, is considered to be thought out and objective.

1 Here composition is to be understood not only in a musical sense, but in the sense of a theater play or literary works.
The composition is recorded in writing ${ }^{2}$ and it is seen in Western culture as superior to the performance. "It is more the substance itself", according to Adorno (in Kurt, 2008: 22). In my opinion, improvisation and composition are no opposites: both elements appear during an action. They are, as Kurt says, two poles in a relationship to each other. On one hand the unforeseeable always bases on the arranged. Without prepared definitions of situations and available reaction patterns not only would we be incapable of reacting at all, far more one would not even be able to experience "the unpredictable", for one lacks the ability to foresee see it coming in the first place (Kurt, 2008: 41).

Depending on how far an action leans to one side, the extent of an improvisation will be larger or smaller, due to the fact that the action itself is regulated by the situation which one is in. The exact starting and ending point of improvisation is difficult to identify, because improvisation does not exist in a pure form (Landgraf, 2010: 77).

Every creation in a way has to be composed respectively invented or made up. The process of improvisation is relatively fast that is why with improvisation the invention and realization is happening at the same time. It is based on the simultaneity of production and performance (Kurt, 2008: 25f). Consequently, improvisation is action in real-time with a strong emphasis on the current happenings (Figueroa-Dreher, 2008a: 166) 3 . In fact, while improvising there is only time to think about

2 Written tradition is highly important to Western culture. Because improvisation is not able to be based in a written form, it is not perceived to be of a high value.

3 It might be one of the breakthroughs of the recent research on improvisation, that the draft cannot be antecedent to an action, as the established action theories state (Figueroa-Dreher 2008b). 
your action, while acting as opposed to nonimprovised action where one can develop and think up a certain concept.

An important point to define improvisation in greater detail is its special status between freedom and limitation due to binding to rules $^{4}$. In most cases one associates improvisation with a great freedom of action "one can do as one pleases". But one should look more closely at it again. Indeed during improvisation there is a great freedom for the performer, many elements of an action appear to be open ended at first and so it seems one can perform without any preparations or boundaries of any kind. Nevertheless the performance itself is only the tip of the iceberg, according to Hall (1992: 25). Generally, improvisation is on the one hand like any kind of performance free and without boundaries, on the other hand it depends on specific cultural concepts (Kozlarek, 2008: 65). As mentioned above, a performance would not be possible without any kind of routine schemes of performance or reactions; therefore one must be able to return to pre-composed patterns of performance (Hall, 1992: 25). That means that there are norms, rules and laws one must follow so that improvisation can take place. Improvisation would not be recognizable as such if the unforeseeable would not emerge from a distinct structure (Bormann et al, 2010: 9). Improvisation in music and theatre is mostly a group process which means that it is a process of interaction. When several people act together certain rules must be established.

That does not necessarily mean that rules must be formulated or that the performers must be aware of them, because the rules arise during improvisation (Sawyer, 2001: 16f).

4 The word "rules" here does not mean explicitly formulated regulations of actions, but implicit norms of action.

\section{Improvisational theatre}

The predecessor of today's improvisational theatre and the first form of improvisational theatre is the "Commedia dell'arte", also known as "Commedia all improvvisio" or "italienische Stegreifkomödie". Commedia dell'arte uses a static plot, where beginning and end are defined in advance, whereas the exact text and therefore the dialogue is improvised by the artists (Wolff, 1933: 85). The commedia dell arte is a product of the Renaissance originating in Italy, probably as an alternative to the classical comedy and the "scholarly comedy". The specialty of the Stegreifcomedy was that the specific characters could be recognized by their costumes and masks and so the same characters with the same traits appeared in different plays, e.g., the well-known Harlekin.

It is arguable to what extent one can talk about improvisation in this case, because the plays had been rehearsed long before to avoid breaks on stage. Additionally, all actors had their specific roles and the plays remained the same over a longer period of time, this lead to a repetition of dialogues (Molinari, 1975: 166; Wolff, 1933: 86). However, commedia dell'arte uses some improvised elements which depict a totally new concept opposite the classical, literary theatre. Commedia dell arte did influence further developments that lead to the present form of improvisational theatre.

At the beginning of the $20^{\text {th }}$ century, Jacques Copeau adapted some techniques of the commedia dell'arte, thus changing the French theatre. In Russia, Freud's psychoanalysis influenced Konstantin Stanislavsky who began with character improvisation, to see behind the script and to gain a better understanding of a specific character. The first improvisational theatre on stage was the "Theater der Spontaneität (theatre of spontaneity)", founded by 
Moreno in Vienna in 1923. This had a decisive influence on the development of the theatre in the USA. Viola Spolin foremost designed various improvisational-plays in the 1930's and 1940's. In 1955, in Chicago, her son founded a theatre group and made use of these plays. This provided the ground for shaping the "Classic Chicago Improv" where neither character nor plot is pre-planned (Sawyer, 1999: 33). Improvisational theatre has been spreading since the mid 1950's, whereby two different styles have crystallized: on the one hand groups that use suggestions by the audience for the realization of their improvisational-plays, mostly five minutes long, on the other hand some ensembles have longer plays. These two use the audience as an impulse for performances lasting around 30 minutes. The difference here to the shorter scenes is that more emphasis is placed on the storyline and the characters, whereas the shorter scenes rather emphasize the "joke" (Sawyer, 1999: 34). An important development of improvisational theatre, the so-called theatre sport, was influenced largely by the British Keith Johnston. Due to the censorship in Great Britain, he declared his performances as "sports events" and named them "theatre sport". Usually today during the so-called impromatch two groups play against each other (Das ist Impro, 2004: 1).

\section{Features of the improvisational theatre}

Improvisational theatre "is playing of dramatic scenes without written dialogue and with minimal or no predetermined dramatic activity" (Reck, 2003: 73). Nevertheless it is difficult to define exactly to what extent a play is pre-structured or planned without losing its improvisational character. This is especially linked to the difficulties of describing the concept of improvised acting itself and the various facettes of this type of theatre. One cannot be sure what will happen, one knows only that the play will be performed within a defined frame. Improvisation in this case is unpredictable, but not unanticipated (Matzke, 2010: 174).

Obviously, within the improvisational theatre certain elements of the play are improvised. Often ideas by the audience are taken up to construct a scene, e.g., when it is a question of location, object or motif. A feature of the improvisational theatre is the "intertwining of the level of representation and production" (Landgraf, 2010: 79). That means the audience is not only witnessing the performance, but also the creation of a play.

Commonly, during a performance various improvisational games are played. One of the most frequent forms of improvisational theatre is "Theater-Sport", also called "Theatermatch" or "Impromatch", where two opposing ensembles play against each other. After various scenes, the audiences evaluates which ensemble they preferred. The actual number of performers per match varies. On a regular basis the performance is accompanied by one or more also improvising musicians (Das ist Impro, 2004: 1f).

Another important facette of the improvisational theatre in comparison to the classical theatre is the close contact between the actors and the audience. Landgraf even calls that "recoding the space of the theatre" (2010: 69). The audience is given the opportunity to co-create the performance. The "play" itself has shifted from a pure product by the author (performed by the actors) but is generated in dialogue with the audience (Landgraf, 2010: 80 ). Another point is that the actual presence of an audience heightens the situation with expectation. Since the audience is aware of the improvisational character of the play, they don't expect a perfect show, but on the other hand they want to be surprised. They know that what they are seeing has never before been performed in this manner and that they 
will never experience the identical show. They want to be part of a unique experience and one could say they are chosen in comparison to the people who are not present, and therefore cannot witness the creational process (Behne, 1992: 55f). In contrast, Keith Johnston states that the audience prefers to be entertained instead of being aware that the play is an improvisation (Johnston, 2009: 77). Spolin also emphasizes the role of the audience as the most important part of the theater. According to him, it should not be forgotten that the actors share their experience with the audience and without the presence of which the performance would not make any sense (Spolin, 1993: 26f).

The main purpose of the improvisational theatre is that the actions are designed to be humorous. This is due to the special relationship between the audience and the actors, because "comedy relates directly to the audience, whereas tragedy affects the audience indirectly" (Müller, in Landgraf, 2010: 79). Sad and serious scenes do not include the audience as much as comical scenes. The fact that the improvisational theatre is a referral to the present is an important and essential structural element of the comedy and leads to the form of improvisational comedy (Landgraf, 2010: 79).

Improvisational theatre is not a product of an individual like with most musical improvisations, rather it "originates in the cooperation between the interacting performers" (Spolin, 1993: 34). Consequently, theatrical improvisation is a process that also involves the interaction of several individuals. For this exact reason "anything goes" does not apply to the improvisational theatre, one must adapt to and communicate with the others. Keith Sawyer speaks in this context of "group improvisation" and means "neither actor alone can decide what will happen and then impose the decision on the actor. [They] are working together in a collaborative duet" (Sawyer, 2001: 13). Instead of drawing the attention towards oneself and one's own plan one should direct it towards "the group mind" (Sawyer, 2001: 18). For this reason it is extremely important to listen to what the others have to say. Marsalis a musician mentions "My freedom to perform is directly connected with the freedom of others on stage. I had something to say, like they had. If the others were free, I could act freely and vice versa. To be heard also meant that we had to listen to each other exactly" (Marsalis, 2010: 30). This can be transferred to the situation of theatre: a bad actor will diminish the freedom of the improvisation and thus spoil the performance of his co-actors (Matzke, 2010: 30).

However, the moments in which the actors' communication functions best are the most perfect moments of the improvisation.

\section{Theory of action}

Action is a central theme in Sociology, if not the central theme. Defining sociology one often quotes Weber, who describes it as "a science which attempts the interpretative understanding of social action in order thereby to arrive at a causal explanation of its cause and effects" (Weber, 1972: 1f). Studies of the Social Sciences consequently analyze human action. A range of theories of action have been established to explain specific situations during social interaction.

\section{The theory of action by Thomas Luckmann}

In his theory of action, Luckmann studies the structure of actions, following Schütz (Figueroa-Dreher, 2008a: 162). He differentiates between acting and action. "Acting is step-by-step completion of an action, whereas action itself is completed action" (Luckmann, 1992: 48). According to this, 
acting is a temporal process, whilst action is a finished element and it can only gain meaning in retrospect. This meaning cannot be observed, but action can. In order to act at all one must have a draft. That means there is a goal which one wants to achieve via acting. The actors have different levels of awareness of the draft. The action's goal, the completed action, would be what one imagines while first planning the draft. The more uncertain the goal, the more precise the draft is reflected upon.

The draft itself is utopian, because it aims to complete a goal in the future, though the possibility does exist that it will be completed. The imagination is no pure fantasy, but a draft (Luckmann, 1992: 59f). The meaning of the action according to Schütz is the pre-planned action, hence the draft is a mark that allows an interpretation of the action's meaning (Schütz, 2004: 157). The completion of the action is focused on a goal towards which logical steps lead. This is what one especially realizes when something does not happen according to plan. Every step has a purpose, namely to achieve the goal. If you of asked for the "why" of an action, the answer would begin with because and refer to the contextual meaning of the individual steps (Luckmann, 1992: 49f).

Precedent to every action one must decide to act, with routine actions this may happen relatively automatically, but the more unusual an action is the more one has to be aware of the specific step. In any case there is always a threshold to the will of acting as well as a temporal space between the draft and the action itself (Luckmann, 1992: 76). Drafts are also used whilst creating new forms of actions: the actors' experience forms a knowledge base by drafts that consist of typical elements. One must be aware of these elements in contrary to habitual actions (Luckmann, 1992: 66f).
In general, this theory of action is based on rational actions, which can lead to certain difficulties when trying to explain improvisational actions.

\section{Improvisation action and action theory}

Due to the rational character of actions that Luckmann and Schütz emphasize, it seems to be difficult to understand human action as a process by means of this theory. According to Kurt, many actions may not be a realization of clearly designed plans and the "First-thinkthen-act-Theory" so Kurt (2008: 21) does not say much about the social practice. In the theory of action by Luckmann "the situation", for example, is not stressed enough. Whereas in comparison American pragmatism, focuses on the situation and not on the "individual (sovereign) subject” (Kurt, 2008: 37). Joas, too, sees creative acting not as a product of the actor, "but in intersubjective and concrete situations of action" (Kozlarek, 2008: 47). Additionally, Figueroa-Dreher believes that the situation of improvising offers various elements one can refer to whilst acting (2008b: 397). One "lets things happen", since nobody can be sure which elements are part of the actual action.

The thesis that improvisational action does not function according to a specific rational plan seems to be confirmed by the experience of "flow". Improvisation may be an action to be identified by the absence of reflection. Thus no plan or draft is able to guide the action. Nevertheless improvisation means that one is extremely conscious, because various processes frequently fluctuate (Behne, 1992: 50f). This theory, again, refers to the level of interaction. On the one hand, one must open up to the situation, which involves the contribution of others without pursuing one's own plan. Monson sees the drafts shifted to a level of interaction. The draft therefore is 
not a product of an individual, but develops from the interaction of a group (Monson, 1996: 81f).

Apparently, the term "draft" appears to be problematic in connection with "improvisation", particularly since the action targets a present situation and not the future (FigueroaDreher, 2008b: 397).

\section{Empiric part}

Finding an empirical approach to the action itself is not easy, because to grasp the actual meaning of an action in the sense of the theory of action is problematic, since one cannot simply observe the sense of an action. One must search for elements that refer to or point to something. Whether or not an interpretation is justified is always partly speculative. One interprets action, but there is no definite evidence about the correctness of the interpretation (Figueroa-Dreher, 2008b: 391). Nevertheless one can empirically approach an explanation of an action using various methods. With the help of the Grounde Theory (GT), a qualitative analysis will be conducted within the next chapter.

\section{Grounded Theory}

GT, a "methodology and a style to analyze social phenomena" (Legewie, n.d.: 18) was developed by Strauss and Glaser in the 1960's. Hereby the method itself is not strictly stringent, but the process allows the development of a data based theory to develop theories of social behavior. Theories or categories are thus created through a process of data analysis, where all important data can be considered, to satisfy the complexity of the social phenomena (Strauss, 1994: $31 \mathrm{ff}$ ). GT is an inductive approach. That means theories and hypotheses do not exist ex ante -contemplation beforehand is left out on purpose, because this may hinder the perception-, but that either one uses a descriptive approach or one develops "tentative connections" out of the description, whereas these are at first untested speculations (Strauss, 1994: 37f; Merten, 1995: 316).

Consequently, the GT is a suitable method for research of relatively unknown phenomena. The results depend on the analysis of the individual researcher which one puts up with. The postulation of GT that one must conduct the data analysis without pre-contemplation and without being lead by a theory seems unrealistic.

There is always a focus of research, and practical research is impossible without being based on a certain pre-contemplation which hinders a strict GT approach, because one cannot separate between a deductive and an inductive approach (Meinefeld, 2000: 269) ${ }^{5}$.

Analyzing improvisational theatre focuses on "how" improvisational performance is conducted. One tries to figure out the strategies of the actors. To what extent do they use pre-composed patterns of acting, despite the unforeseeable nature of the situation? Are there certain rules or norms the actors adhere to?

\section{Data-analysis}

The recording is based on an Impro-Match of the TmbH-Constanze theatre ensemble and on the "Gorillas" of Berlin'. Sometimes, they perform as a show mostly though in form of an "impro-match". The audience is given voting-cards to determine which team was more successful. Similarly the audience

5 The GT method is not described any further in this paper. For further information on it see Strauss/Corbin, 1996.

6 I want to thank the actors of the TmbH and the Gorilllas for the permit to record the show and to evaluate the gathered data. 
also has the possibility to communicate with the actors during the performance. If one is pleased one may throw roses on to the stage, if one is dissatisfied one may throw a wet sponge $^{7}$, an important feedback for the actors (TmbH Konstanz).

The game analyzed here is the "Zettel-Spiel" (a suggestion card game). During a break the audience is asked to write down wishes, secrets or other ideas on a piece of paper and to put it into a box. During the act, the performers occasionally draw a card and read out loud what is written on it, e.g., here the audience was asked for an unpopular profession. In this case the word "asbestosguy" was suggested and voted for. A scene was developed that started in a university library where a student meets an asbestosguy. During the scene in which the boss of the asbestos disposal company and several employees meet, and it turns out that the company is fraudulent, because the company first built in the asbestos to then "discover" that there is an asbestos contamination ${ }^{8}$.

\section{Results}

Several typical mode of action were able to be identified analyzing the "Zettel-Spiel" with Grounded Theory':

Repetitions are more frequent, the actors repeat words that were mentioned before by others. For example it was noticeable that the

7 One means no harm by throwing the sponge, since it still means that contact to the audience is held.

8 Interested readers may contact me under my email address: Anja.Joos@uni-konstanz.de for the evaluated transcript.

9 I want to thank Pia Oexle for her help analyzing the data. uncommon word "Kornfeld (cornfield)" $" 10$ that had been suggested by the audience reoccurred more than once, e.g., the term cornfield was mentioned several times. Some questions were also repeated. One actor, the asbestosguy asked: "What do you think about 2.500 without tax?" and the actor repeated the question before he answered. "2.500 without tax - what do I think?"11. Likewise non-oral expressions such as gestures are copied ${ }^{12}$. A topic that had been brought up in an earlier game was recycled and put into a new context: In the earlier game the audience was asked if somebody was writing an essay, and what the topic was. Somebody claimed to be writing an essay about pathology. Following that the actor used this essay topic in the scene where he as a student in the library and says: "I'm looking for something about pathology for an essay"13. Why the actors use repetition can only be speculated about. Perhaps because the actors need to gain more time in order to react appropriately, maybe because some expressions are still present in the actors' mind and therefore reoccur.

Another typical mode of action that dominated the scene was that the actors always responded to each other. They did not negate either remarks or each others adaption to a role or other elements of the scene. Even a change of scene is accepted without insisting on continuing. For example the situation where two actors performing actively on stage, a third appears and taps one on the

10 Kornfeld (96/102/105). The numbers occurring in the footnotes show the original quotations and where they can be found in the transcript.

11 S2: "Was halten Sie davon? 2.500 Netto?" S1: “2500 Netto? Was ich davon halte?” (262/265).

12 S2 schlägt 2 mal leicht mit der hand gegen seine Stirn, S4 und s2 schauen sich an, s4 macht dieselbe Bewegung wie s2 (149/151).

13 "Ich such für ne Hausarbeit von Pathologie was" (72) 
shoulder, takes over the conversation with the other, whilst the one who was touched leaves the stage ${ }^{14}$.

In addition an interaction is carried on in a way that the subsequent actor is enabled to continue. The fact that the performers never question the actions of the others could be an indication that the actors share a common draft of action. No one should follow an individual plan, because the reactions of the others involved would be unforeseeable and one could falter. Therefore the draft could be based on the level of interaction and not with the individual actor. In a way one is in a certain situation and to this one adapts.

During their performance the actors observe each other keenly, often they try to maintain eye-contact. In planned scenes however, where a plot exists and where it is agreed upon who speaks when and where one would probably not watch each other so intensely. Only eye-contact guarantees the ability of fast reaction.

Using suggestion cards is rather appealing because their content is not known to the actors. Typically this "unknown element" is dealt with by planning to a certain extent while acting, when to read out loud a card's content, designing one's sentence accordingly. Mostly one begins the sentence such that the contents of a card depict a statement, e.g. "Do you mean a bed in a cornfield?"15. Once a card is spoken out loudly, the actors instantly try to incorporate it into the story: "A bed in a cornfield is more harmful than

14 S4 kommt in die Mitte der Bühne, tippt s1 auf die Schulter, wendet sich Richtung s2, s1 geht nach rechts an die Seite, $s 2$ geht einige Schritte nach links (133).

15 S1: Wo wolln sie damit etwa sagen "ein Bett im Kornfeld" (96) (This refers to a widely known song in German with the same title). sitting here?"16. Most of the time the method does not block the story's development, yet sometimes it leads to a dead-end. Answering the question why "Asbestos... "need a Christmas tree someone says "the critter is so real it even has hairs on it's behind", this situation seems to be so absurd that the only answer was "oh, yeah (ach so)"17. In this case, the actors change of scenes and ignore the afore said. In similar situations either an actor who was non-active changed the scene or the performing actor altered "the topic" itself. Typical modi of action can be found dealing with the progress of the story. Generally one tries to stick to the antecedent story and to build up on it with open end. The actors have a myriad of possibilities on how the plot can move on, nevertheless they are limited by the logic of the plot. A good example is the "asbestos-guy" who reanimates the "University of Constance" and the "job" via his statement giving the story a whole new direction by saying, "I will spread out the asbestos"18. Usually the plot illustrates the improvisational character of the story. What was said before applies to the "Zettel-Spiel" as well. Although the "Zettel-Spiel" did have a meaningful end, it could have turned out differently can only be speculated if the asbestos-company would be successful with their plan to spread asbestos at the university. If the plot had been premeditated this question would probably have been answered. Taking the non-oral level into consideration some implicit and explicit rules seem to exist. Gestures by body language are recognized and accepted.

Tapping the another actor's shoulder and moving to stand in front of him is used to signal the other player that oneself is now part of

16 S1: is schädlicher (-) als hier zu sitzen? (98).

17 S4: "Das (vieh) ist so echt, das hat sogar Haare am Hintern"; S2: "Ach so! ” (145)

18 S3: "Ich werd d das Asbest verteilen" (134). 
the scene to take the other's place. Also there is an area in the middle of the stage where actors may be engaged in a conversation and are active. Along the edge of the stage they are passive. It is accepted if a player does not want to be involved, the initiative lies in every individual.

To what extent a routine is present can only be speculated. In order to discern a valid result one would have to study the actor's behavior across several games or shows. One may assume though these type of games are known to the actors and that they have a routine in dealing with them. Probably the actors gathered the experience that they can integrate a card's content more easily if they begin the sentence accordingly. Connected with this assumption one may additionally assume that the actors know due to their routine that the audience often proposes current affairs. The Constance university library where the play took place was closed a few days before due to asbestos contamination. Perhaps the Constance and Berlin actors of both groups discussed regional hot topics, the actors at least seem to know about this particular hot topic concerning the asbestos-contamination.

The routine and the knowledge about "how to play the games" and maybe even how to estimate the kind of suggestions the audience offers could be called "Knowledge-Base" and "Repertoire". Studies on improvisational musicians have found out that it is exactly this routine that allows the improvisation itself, this attribute could be similar with the improvisational theatre.

Modus operandi such as repeating, responding, observing, dealing with unknown elements, linking interaction and other rules, that have been identified within this study show how improvisational action can take place.

\section{Conclusion}

This essay had the purpose to look closely into improvisational actions in the context of the improvisational theater. It was shown that improvisational actions are located on different points of a continuum and are moving between improvisation and composition. Within the play on the one hand something new is created and on the other hand improvisational actions refer to something that is already known.

The status between freedom and restrictions was able to be confirmed. Even if there is a large variety of possibilities for action, improvisation seems to be limited by certain rules, e.g. responding to each other. These implicit rules have become visible by observing the typical repertoire of actions which are identified as a part of Grounded Thory. The question how far actions are designed is very difficult to answer: the actual plot may not be prepared, yet one can quickly plan to perform a specific action, the dividing line is hard to define.

At that point more research has to be done, a cooperation between social and cognitive sciences could be fruitful, because for researchers with social sciences background it is difficult to discover the speed in which actions can be planned. Occasional pauses that occur e.g. by varying the speed of speech, repetitions or during applause may be used by the actors to develop a plan. It becomes clear that time is a factor that imposes a limit on the actor's planning possibility. The actor cannot know what reaction he will receive which makes the realization of a planned storyline impossible. The story evolves with the interacting contribution of all performers. Thus, Monson's theory that the planning of drafts happens on the various levels of interaction, is valid. Varied mentioned actions, characters and events created through interaction occur 
only through dialogue. Finding an explanation via the phenomenological theory of action seems difficult.

This paper's conclusion show that the symbolic interaction theory of action might be more appropriate as an explanation. Consequently, further analysis is needed. Body language could not be given much space in this paper, but as a very important improvisational component of interaction, more research is required in this field. Furthermore it would be interesting to interview the actors, to take their point of view into account and to compare it with an external view. However, could be shown in this paper is that by looking into this topic notable elementary components of the improvisational theatre could be identified

The improvisational theatre has opened up a bit, but it has not yet revealed all its secrets.

\section{References}

Behne, K.E. (1992). Zur Psychologie der (freien) Improvisation. In Fähndrich, W. (Ed.). Improvisation. Winterthur: Amadeus.

Bormann, H.F. et al. (2010). Improvisieren. Eine Eröffnung. In Bormann, H.F. et al. (Eds.). Improvisieren. Paradoxien des Unvorhersehbaren. Bielefeld: Transcript.

Das ist Impro (2004). In Impro-Theater. Das zentrale Portal für Improvisationstheater. Http://www.impro-theater.de/index.php/ das-ist-impro.html. 09.05.2011

Figueroa-Dreher, S.K. (2008a). Musikalisches Improvisieren. Ein Ausdruck des Augenblicks. In Kurt, R. \& Näumann, K. (Eds.). Menschliches Handeln als Improvisation. Sozial und musikwissenschaftliche Perspektiven. Bielefeld: Transript.
Figueroa-Dreher, S.K. (2008b). Musikalisches Improvisieren. Die phänomenologische Handlungstheorie auf dem Prüfstand. In Raab, Jürgen et al. (Eds.). Phänomenologie und Soziologie. Theoretische Positionen, aktuelle Problemfelder und empirische Umsetzungen. Wiesbaden: VS-Verlag.

Hall, E.T. (1992). Improvisation, Ein Prozess auf mehreren Ebenen. In Fähndrich, W. (Ed.). Improvisation. Winterthur: Amadeus.

Johnston, K. (2009). Theaterspiele. Spontaneität, Improvisation und Theatersport ( $7^{\text {th }}$ ed.). Berlin: Alexander-Verlag.

Kozlarek, O. (2008). Theoretisch-begriffliche Anschlussstellen für ein Verständnis menschlichen Handelns als Improvisation. In Kurt, R. \& Näumann, K. (Eds.). Menschliches Handeln als Improvisation. Sozial und musikwissenschaftliche Perspektiven. Bielefeld: Transcript.

Kurt, R. (2008). Komposition und Improvisation als Grundbegriffe einer allgemeinen Handlungstheorie. In Kurt, R. \& Näumann, K. (Eds.). Menschliches Handeln als Improvisation. Sozial- und musikwissenschaftliche Perspektiven . Bielefeld: Transcript.

Kurt, R. \& Näumann, K. (2008). Einleitung. In Kurt, R. \& Näumann, K. (Eds.). Menschliches Handeln als Improvisation. Sozial und musikwissenschaftliche Perspektiven. Bielefeld: Transcript.

Landgraf, E. (2010). Eine wirklich transzendentale Buffonerie. Improvisation und Improvisationstheater im Kontext der frühromantischen Poetologie. In Bormann, H.F. et al. (Eds.). Improvisieren. Paradoxien des Unvorhersehbaren. Bielefeld: Transcript. 
Legewie, H. (n.d.). Vorlesung: Qualitative Sozialforschung und der Ansatz der Grounded Theory. In www.ztg.tu-berlin. de/download/legewie/Dokumente/Vorlesung_11.pdf. 10.05.2011

Luckmann, Th. (1992). Theorie des sozialen Handelns. Berlin: de Gruyeter.

Marsalis, W. (2010). Jazz, mein Leben. Von der Kraft der Improvisation. München: Siedler Verlag.

Matzke, A. (2010). Der unmögliche Schauspieler. Theater-Improvisieren. In Bormann, H. (Eds.). Improvisieren. Paradoxien des Unvorhersehbaren. Bielefeld: Transcript.

Meinefeld, W. (2000). Hypothesen und Vorwissen in der qualitativen Sozialforschung. In Flick, U. et al. (Eds.). Qualitative Forschung. Ein Handbuch. Reinbek: Rowohlt.

Merten, K. (1995). Inhaltsanalyse. Einführung in Theorie, Methode und Praxis ( $2^{\text {nd }}$ ed.). Opladen: Westdeutscher Verlag.

Molinari, C. (1975). Die Commedia dell arte. In ders., Theater. Die faszinierende Geschichte des Schauspiels. Freiburg i.B.: Herder.

Monson, I. (1996). Saying somthing. Jazz Improvisation and Interaction. Chicago: The University of Chicago Press.

Reck, H.U. (2003). Vom regulären Spiel der Einbildungskräfte zur Suggestivität des offenen Kunstwerks - Aspekte zu einer Kunstgeschichte des Improvisierens. In Fähndrich, W. (Ed.). Improvisation, 5, 61-98. Winterthur: Amadeus.
Sawyer, K.R. (1999). Improvisation. In Runco, M.A. \& Pritzker, S.R. (Eds.). Encyclopedia of Creativity, 2, 31-38. San Diego: Academic Press.

Sawyer, K.R. (2001). Creating Conversations. Improvisation in Everyday Discourse. New Jersey: Hampton Press.

Schütz, A. (2004). Der sinnhafte Aufbau der sozialen Welt. Eine Einleitung in die verstehende Soziologie. In Endreß, M. \& Renn, J. (Eds.). ASW II. Konstanz: UVK.

Spolin, V. (1993). Improvisationstechniken für Pädagogik, Therapie und Theater $\left(4^{\text {th }}\right.$ ed.). Paderborn: Jungfermann.

Strauss, A.L. (1994). Grundlagen qualitativer Sozialforschung. Datenanalyse und Theoriebildung in der empirischen soziologischen Forschung. München: Fink.

Strauss, A.L. \& Corbin, J. (1996). Grundlagen Qualitativer Sozialforschung. Weinheim: Psychologie Verlags Union.

TmbH Konstanz (n.d.). Was für ein Theater? In http://www.tmbh.com/im pro.html

Weber, M. (1972). Wirtschaft und Gesellschaft - Grundriss der verstehenden Soziologie ( $5^{\text {th }}$ ed.). Tübingen: Mohr Siebeck Verlag.

Widmer, P. (1994). Aus dem Mangel heraus. In Fähndrich, W. (Ed.). Improvisation, 2, 9-20. Winterthur: Amadeus.

Wolff, M.J. (1997). Die Commedia dell`arte. In Theile, W. (Ed.). Commedia dell arte. Geschichte, Theorie, Praxis. Wiesbaden: Harrassowitz. 